Article

\title{
Pricing or Quota? A Solution to Water Scarcity in Oasis Regions in China: A Case Study in the Heihe River Basin
}

\section{Minjun Shi ${ }^{1,2, *}$, Xiaojun Wang ${ }^{1,2}$, Hong Yang ${ }^{3}$ and Tao Wang ${ }^{4}$}

1 School of Management, University of Chinese Academy of Sciences, Beijing 100190, China; E-Mail: xjwang86@gmail.com

2 Research Centre on Fictitious Economy \& Data Science, Chinese Academy of Sciences, Beijing 100190, China

3 Swiss Federal institute for Aquatic Science and Technology (Eawag), Ueberlandstrasse 133, Duebendorf 8600, Switzerland; E-Mail: hong.yang@eawag.ch

4 Cold and Arid Regions Environmental and Engineering Research Institute, Chinese Academy of Sciences, Lanzhou 730000, China; E-Mail: wangtao@1zb.ac.cn

* Author to whom correspondence should be addressed; E-Mail: mjshi@ucas.ac.cn; Tel./Fax: +86-10-8628-0911.

External Editor: Ram Babu Singh

Received: 10 August 2014; in revised form: 14 October 2014 / Accepted: 20 October 2014 / Published: 29 October 2014

Abstract: The conflict between increasing water demand and limited water resources has become a serious threat to oasis regions in China. Solutions to water scarcity have to curb overall water demands, especially reducing agricultural water use. Price control and quantitative control are the two most commonly applied policy instruments for water demand management. This paper used a bio-economic model (BEM) to examine the shadow price of water resources and to investigate farmers' response to water demand management policies in water scarce regions based on a study in the Heihe River Basin in northwest China. The results indicate that farmers are not very responsive to changes in water price, because it is currently far below the shadow price of water resources in most irrigation zones. A reduction of agricultural water demand could occur only with a large rise in the water price. In comparison, a quantitative control measure is more effective at reducing water use. Concerning the effects on farm income, a price control will cost much more than a quantitative control to save the same volume of water. Hence, a water quota is a more 
suitable choice for the purpose of reducing agricultural water use, while minimizing farm income loss in the region of this case study.

Keywords: agricultural water use; bio-economic model; water demand management; water price control; water quota

\section{Introduction}

The conflict between increasing water demand with population growth, economic development and limited water resources has become the most serious threat to oasis regions in China. Competition for water between upstream and downstream regions often results in a decrease in river flows to downstream regions. Farmers in downstream regions have to increase mining extraction of groundwater to fill the gap between water demand and supply. Groundwater over-exploitation and decline in groundwater tables have caused severe ecological degradation and desertification in downstream regions [1,2]. In order to alleviate water scarcity in downstream regions, water reallocation from upstream to downstream regions has been implemented in some river basins in oasis regions, notably the Heihe River Basin and the Shiyang River Basin in northwest China. However, the reallocation of water resources has not solved the water scarcity problem in these river basins. The total water demand is still increasing, particularly with industrialization and urbanization, which tends to heighten water scarcity. The solution to water scarcity and ecological degradation in oasis regions is to stop the growth in water demands, especially reducing agricultural water use. The experiences of some river basins in oasis regions indicate that the extension of water saving irrigation techniques can improve water use efficiency, but not necessarily lead to an automatic decrease in water use, as the saved water is often used to expand irrigation [3]. To cap the total water demand on the river basin scale while meeting the rising water demands for industrialization and urbanization, there is a need to reduce agricultural water use through water demand management and reallocating the saved water to the industrial and domestic sectors.

Among various policies in reducing agricultural water use, the two most commonly applied are water price control and quantitative control, corresponding to a market mechanism and administrative management, respectively. There is a large literature on the theoretic basis and the effects of these two policy instruments for water demand management. Theoretically, the choice of policy instrument depends critically on the curvature of cost and benefit functions around the optimal output level. However, in practice, many "non-economic" factors can play decisive roles in determining the effectiveness of different policy instruments for water demand management [4].

For agriculture, the low price of irrigation water has been commonly considered as a primary cause of excessive water use [5]. With this view being prevalent, it comes as no surprise that raising water prices is widely promoted as a key measure for dealing with water shortage. In general, the reasons for supporting a price instrument include: (1) the stimulus to obtain a profit maximizing output is built right in if producers are rewarded in proportion to profits; and (2) raising prices to bring about water conservation is less costly than implementing a command-and-control approach, because it is easier to set a uniform price than imposing personalized quantities [4]. Therefore, getting prices right is seen as an essential prerequisite for allocating water resources through the price mechanism. 
In practice, the effects of the price mechanism are mixed. Some studies found that water pricing is an effective way to improve water allocation and to encourage water conservation [6-8]. However, many other studies found that the price mechanism has failed to generate a force for water conservation [9-13]. One of the reasons is because water demand becomes elastic only beyond the marginal value or opportunity cost of water [14-16]. When water is considered a public good, it is generally priced low. Hence, the price elasticity of water demand is generally low, especially in developing countries [14-16]. Many researchers have derived the price elasticity of water demand in irrigation based on econometric and mathematical programming models and verified the low price elasticity of irrigation water demand [17-20].

In contrast to price control, quantitative control is another common approach to alleviate water shortage. When water is scarce, the surest and most direct way to make customers use less water is to limit supply [21]. Other reasons for advocating a water quota include equality, transparency, administrative simplicity and relatively low transaction costs [22]. In practice, water quotas are often adopted as a mechanism to curtail demand [23-25]. If water quotas are tradable, it is possible to reallocate water rights among users according to the criterion of economic efficiency. However, quantitative control has its drawbacks. A commonly mentioned one is that measuring and monitoring water use is very difficult and costly [26]. Especially in developing countries, irrigation facilities are in poor condition, and agriculture consists of many small farmer households. Moreover, quantitative control lacks flexibility in response to changing circumstances. Once water quotas have been defined, it is difficult to readjust when water supply mismatches the water use [12].

In China, reducing agricultural water use is one of major objectives of water policies. However, pricing irrigation water remains a controversial issue. It has been widely recognized that irrigation water charges have been very low for a long time and are insufficient to recover water supply costs [2,27]. The thrust of increasing the irrigation water price comes from the consideration of fully recovering water supply costs, as well as reducing water use [16]. Huang et al. (2010) revealed that demand for irrigation water is price elastic when incorporating resource constraints. When water price was increased to the level of the value of marginal product (VMP), farmers will respond to increases in water prices [16]. On the other hand, many studies have also warned of the negative effects of a higher water price on crop production, farm income, food security and social inequality [16,27-29]. A higher water price often forces farmers to switch to low water consuming crops, which often have lower net profit $[9,11,13]$. For example, Liao et al. (2008) conducted an empirical analysis of the impacts of irrigation pricing reforms in the three irrigation districts in northern and southwestern China. They found that water price increases have perverse impacts on agricultural output and farm income. This is because under the current institutional setting and socio-economic conditions in the studied areas, farmers' crop choices were not significantly responsive to water prices. The decrease in output and increase in production costs result in a decrease in net benefits to farmers and overall farmer income [27]. The study by Shen et al. (2010) in Xinjiang found that water management is deeply tied to the political, social and economic conditions of the state. Increasing water price has not contributed to a fairer and more efficient use of scarce water resources, but rather, it has been applied to achieve other political and economic goals, as well as to strengthen a powerful and rapidly growing bureaucracy [30]. Webber et al. (2008) pointed out that the inefficiency of farmers' water use arises in large part from the manner in which water is delivered to them. The system offers no rewards for care in the use of water and, instead, rewards greed. Raising 
the water price without reforming the management system will affect farmers' income and enlarge inter-sectoral inequity, with farmers becoming worse off in comparison to urban dwellers [29].

In the literature, thus far, studies have focused mainly on water pricing and paid much less attention to the effect of quantitative control. Furthermore, assessment of the effectiveness of the correct price signal has not clearly distinguished groundwater and surface water. In rural China, the current irrigation charge for surface water is about $0.05-0.10$ Yuan per $\mathrm{m}^{3}$ (USD $1 \approx$ Yuan 6.3 as of 2012), while the irrigation cost of groundwater is about $0.2-0.3$ Yuan per $\mathrm{m}^{3}$ [16,27]. Raising the surface water price to the level of VMP would cause several negative impacts on crop production and farm income compared to raising the groundwater price. Hence, the assessment of the effects of pricing control should distinguish between groundwater and surface water.

This study aims to assess the impacts of the price control and quota mechanisms on agricultural water use and associated changes in farm income. It compares the effectiveness of these two policy instruments in water scarce regions based on a case study of the Heihe River Basin in northwest China. The key focus is on the shadow price, which is estimated as the marginal product value based on the production function approach in the literature [19,20,31]. The basic hypothesis is that the current water price is far below the shadow price. Farmers will not respond to water price change until it is raised to the level of the shadow price. However, raising the water price to the level of the shadow price will cause severe negative impacts on farm income and crop production. In the case of a water price far below the shadow price, a water quota mechanism might be more realistic and cost effective. A bio-economic model (BEM) is used to examine the shadow price of irrigation water and to simulate farmers' behaviors in response to price control and quantitative control. The levels of compensation under the two policy measures are also examined. Compared with the production function approach in examining the shadow price, the advantage of the bio-economic model approach is to provide dynamic insight into water scarcity when the resource constraint changes.

Using the case study of Heihe River Basin, this study will specifically contribute to the relevant literature on the effectiveness of water pricing and water quota concerning water scarce oasis regions where reducing total water consumption in irrigation is the key. Meanwhile, our BEM model is constructed at the irrigation district level. The spatial variations of the impacts of the two policy measures on farm income and crop production in different irrigation districts will be examined explicitly. By quantitatively determining the shadow price and the effects of the two policy measures with consideration of spatial variations, this study will shed light on agricultural water management in water scarce regions and provide a reference for implementing compensation schemes to alleviate the negative impacts on farm income and food security.

\section{Description of the Heihe River Basin}

The Heihe River Basin is located in the central part of the Hexi Corridor. It is an inland river basin in northwest China and covers an area of approximately $128,000 \mathrm{~km}^{2}$. The mean annual precipitation decreases from $250 \mathrm{~mm}$ to $100 \mathrm{~mm}$ from south to north. The middle stream and part of the upstream of the Heihe River Basin are located in Zhangye City of Gansu Province, and the downstream is located in the Ejin Banner of Inner Mongolia (Figure 1). Zhangye City consists of six counties: Ganzhou, Linze and Gaotai in the middle stream of the Heihe River Basin and Minle, Shandan and Sunan Yugur 
autonomous county in the upstream. The upstream tributaries of the Heihe River Basin are independent and do not flow into the mainstream of the Heihe River.

Figure 1. Location of the study site and 31 irrigation zones.

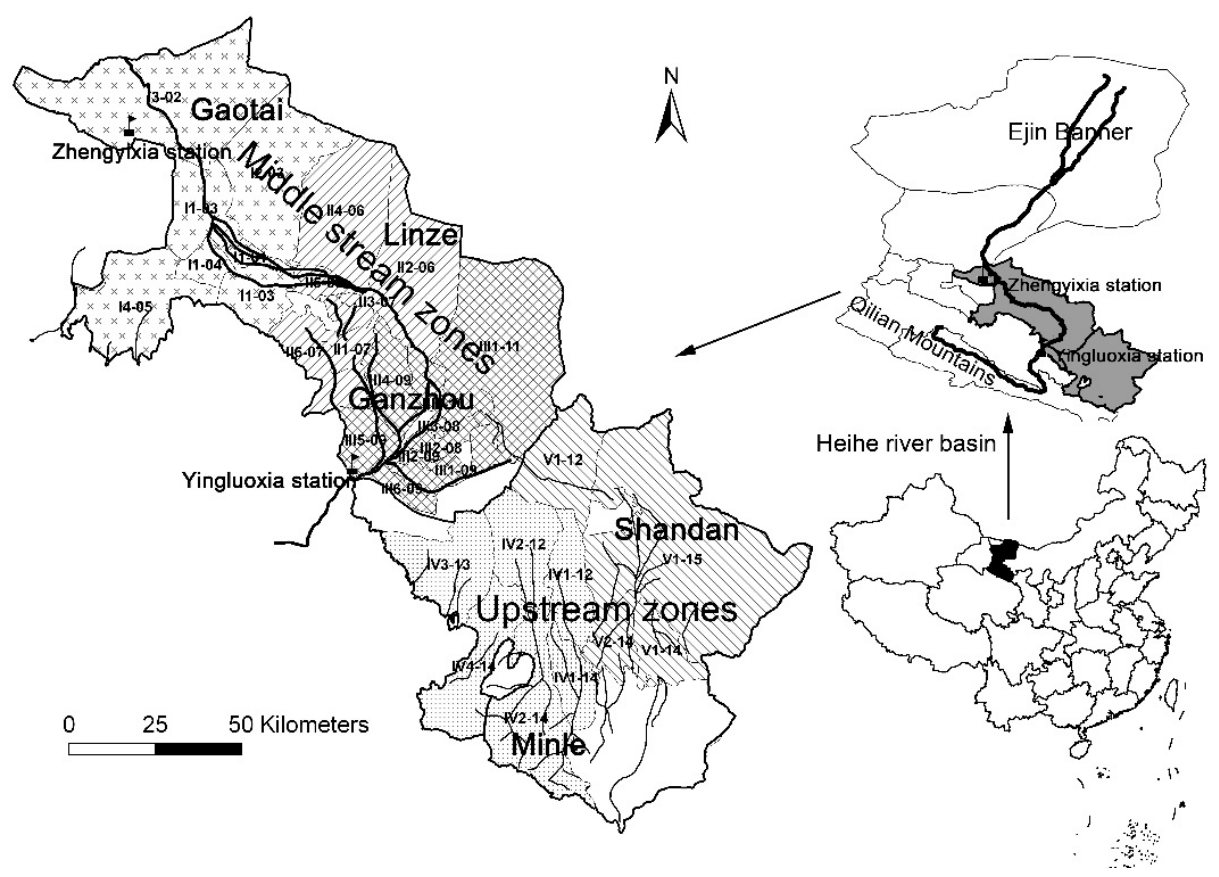

Economic growth in Zhangye caused a rapid increase in water consumption of the middle stream, especially since 1980, and a decrease in river flows to the downstream regions. For example, the runoff at the Zhengyixia station has decreased from 1160 million $\mathrm{m}^{3}$ per year in 1949 to 770 million $\mathrm{m}^{3}$ per year in the 1990s, resulting in ecological degradation and desertification in the downstream regions of the Heihe River Basin. In order to increase runoff to the downstream regions, a water reallocation plan has been implemented in the Heihe River Basin since 2000. Water allocated to downstream regions is determined according to the runoff at Yingluoxia station in the middle stream. If the runoff at Yingluoxia station reaches 1580 million $\mathrm{m}^{3}$, the runoff to the downstream regions should be 950 million $\mathrm{m}^{3}$. This means a water allocation of 630 million $\mathrm{m}^{3}$ to the middle stream. However, water consumption in the middle stream in 2000 was about 1150 million $\mathrm{m}^{3}$, including 310 million $\mathrm{m}^{3}$ from groundwater. Therefore, the middle stream needs to reduce water use to comply with the allocation plan. To reduce the water consumption, a "water-saving society plan" has been implemented since 2002. The concrete measure includes adjusting cropping system, extending water-saving irrigation, reducing irrigation quota, introducing water use permit and water use rights transactions and reducing water loss in irrigation [1,32].

During the past decade, there were significant changes in the cropping system in the Heihe River Basin. Breeding of seed corn and vegetables increased, while the corn-wheat intercrop area decreased. The total sowing area increased steadily, even after 2002. Because of relatively higher water productivity and net profit of seed corn, the substitution for the corn-wheat intercrop has led to an increase in farm income. However, the total irrigation water consumption of Zhangye did not decrease during the past decade, because the saved irrigation water was used for growing vegetables and other crops. One of the reasons is that irrigation water allocation was not strictly implemented. The actual water consumption 
of Zhangye was 1383 million $\mathrm{m}^{3}$ in 2008 , much higher than the allocated water of 1054 million $\mathrm{m}^{3}$. As a result, the runoff to the downstream is less than the entitled amount in the water allocation plan.

The experience of the Heihe River Basin indicates that improvement of water productivity does not necessarily lead to a decrease in water use. Farmers' behavior to pursue the maximization of profit drives them to use saved irrigation water for growing vegetables and other crops. The loose enforcement in irrigation water allocation also offset the effects of water-saving efforts [3,33].

On the other hand, continuous industrialization and urbanization have generated persistent increasing demand of water. According to the Zhangye five-year economic development plan, the industrial water use at the middle stream regions is projected to increase by about 77 million $\mathrm{m}^{3}$ by 2015 and 273 million $\mathrm{m}^{3}$ by 2020 . The total industrial water use will reach 106 million $\mathrm{m}^{3}$ in 2015 and 302 million $\mathrm{m}^{3}$ in 2020. To meet the increasing industrial water demand, agricultural water use has to be reduced. A more strict regulation on water demand is needed in the Heihe River Basin. The Zhangye Water Bureau is considering doubling the irrigation water charge in order to cut irrigation water use.

\section{Analytical Framework}

\subsection{Characterization of Quantitative Control and Price Control}

Quantitative control and price control have different characteristics in regards to their effectiveness in reducing water use and impacts on farm income and food production. The shadow price plays a key role in determining the effects of price control on water demand. The shadow price is defined as the rate of change of the optimal value function with respect to the change of the amount of a resource. It can be calculated by means of the duality theory of linear programming. The shadow price reflects the scarcity of resources and the marginal benefit of resource use [34].

Figure 2 illustrates the effects of quantitative control and price control. Reducing the water quota may directly bring a decrease in water use. If water allocation was reduced from $\mathrm{Q}_{0}$ to $\mathrm{Q}_{1}$, it will lead to a benefit loss $\mathrm{ABB}_{0} \mathrm{~A}_{0}$ (the shadow part in Figure 2a), when water price is kept as $\mathrm{P}_{0}$. Meanwhile, the shadow price of water resources will rise from $\mathrm{P}_{\mathrm{s} 1}$ to $\mathrm{P}_{\mathrm{s} 2}$.

Figure 2. The effects of quantitative and price controls. (a) Quantitative control (reduction of water quota); (b) price control-high shadow price; (c) price control-low shadow price.

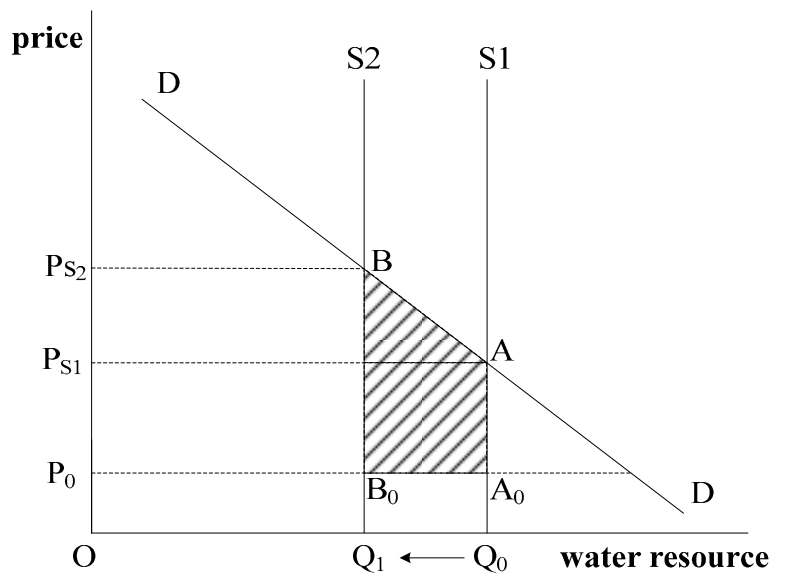

(a)

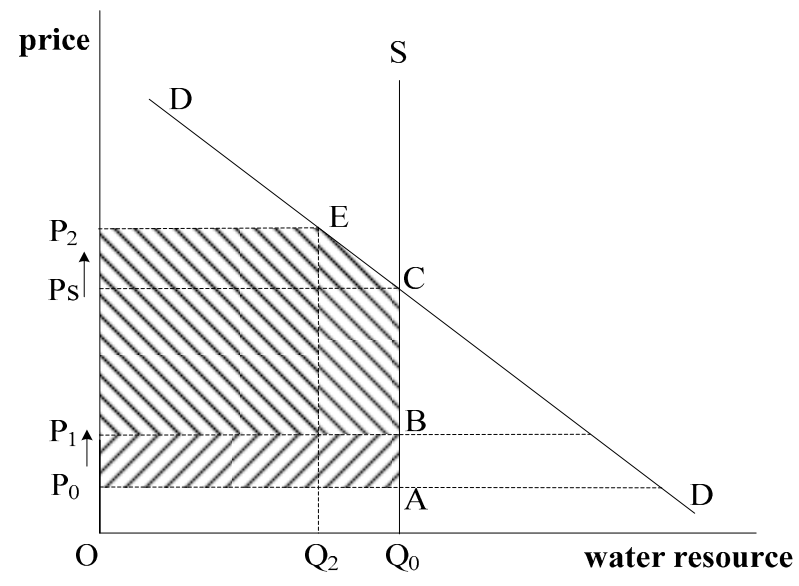

(b) 
Figure 2. Cont.

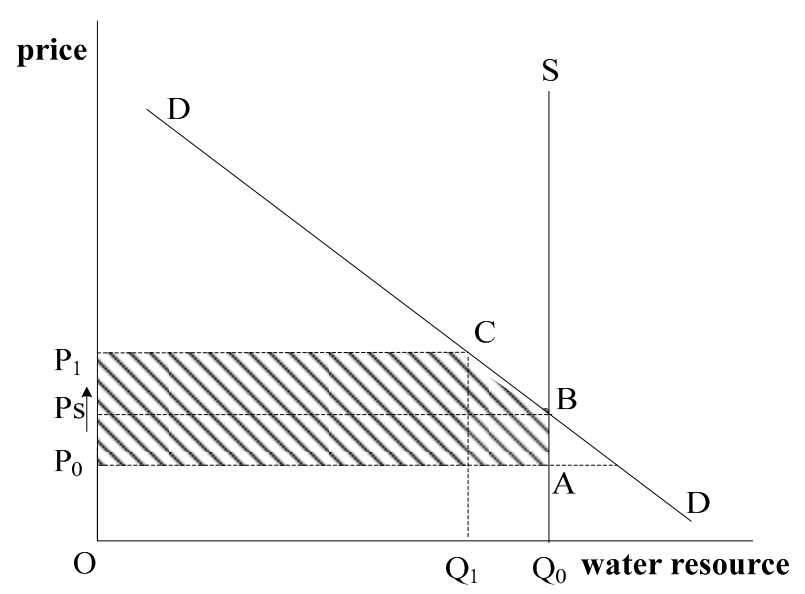

(c)

The effects of the price control vary in two cases, according to the relationship between the existing water price and the shadow price. When water price $\mathrm{P}_{0}$ is far below the original shadow price $\mathrm{P}_{\mathrm{s}}$ (Figure $2 b$ ), raising water price $\mathrm{P}_{0}$ to level $\mathrm{P}_{1}$ has no effect on water use (keeping $\mathrm{Q}_{0}$ constant), but the benefit will decrease by $\mathrm{P}_{0} \mathrm{ABP}_{1}$. Only when the water price is raised from $\mathrm{P}_{0}$ to $\mathrm{P}_{2}$, which is higher than the shadow price, water use will decrease from $\mathrm{Q}_{0}$ to $\mathrm{Q}_{2}$. In this case, the concomitant benefit loss of $\mathrm{P}_{0} \mathrm{ACEP}_{2}$ (the shadow part in Figure $2 b$ ) will be quite large. In the case of water price $\mathrm{P}_{0}$ close to the shadow price $\mathrm{P}_{\mathrm{s}}$ (Figure 2c), a water price rise from $\mathrm{P}_{0}$ to $\mathrm{P}_{1}$, which is higher than the shadow price, water use will decrease from $\mathrm{Q}_{0}$ to $\mathrm{Q}_{1}$. This will cause a benefit loss of $\mathrm{P}_{0} \mathrm{ABCP}_{1}$ (the shadow part in Figure $2 \mathrm{c}$ ).

\subsection{The Bio-Economic Model}

In this study, a bio-economic model (BEM) is developed to link household economic activities with crop production activities. The BEM model can simulate household behaviors to pursue profit maximization under certain resource constraints $[35,36]$. The definition of variables in the BEM model is given in Table 1.

The objective function consists of the production decision and marketing decision. In the case study areas, most farmers earn their livelihood through household businesses by using family labor. Meanwhile, they consume a portion of the products produced on the farm. Consequently, households make a combined decision on production and consumption under the constraints of their resource endowment. Hence, the production decision and consumption decision are incorporated simultaneously into the overall objective function. Usually, crop production and livestock production are combined in farm households, as crops provides feed to livestock and livestock provide organic fertilizer for crop production. Therefore, in the BEM model, the decision variables include the crop mix distribution, livestock structure and consumption structure. Farmers determine the crop mix distribution, e.g., the area $\left(A_{c g}\right)$ devoted to each activity (crop $c$ ) and the number of each domestic animal (livestock V). Furthermore, farmers determine their purchases of consumption goods combined with self-sufficient food production.

In this study, the BEM model uses the Leontief production function of crop and livestock, which is constructed based on the Leontief input-output coefficients. The Leontief production function deals with 
productive technology as a nexus of varied inputs. The input-output coefficients of crop production include seeds, irrigation, fertilizer, pesticide, labor force, capital, and so on. The livestock inputs include feed, fodder, labor, capital, and so on.

Table 1. Variable definitions.

\begin{tabular}{|c|c|c|c|}
\hline Variables & Explanation & Variables & Explanation \\
\hline$M$ & Net income & $N$ & Amount of available loan \\
\hline$M_{0}$ & Cash income in the base year & $\mathrm{D}$ & Subsidy to farmers \\
\hline$x$ & $\begin{array}{l}\text { A vector of inputs used in production } \\
\text { of crop } c \text { or livestock } v\end{array}$ & $i$ & Type of vectors of input $x$ \\
\hline$g$ & Land type of cultivated land & $c$ & Crop \\
\hline$A$ & Land endowment & $P$ & $\begin{array}{l}\text { Price of crop output, livestock output or } \\
\text { purchased food }\end{array}$ \\
\hline$A_{r}$ & Area of rangeland & $A_{c g}$ & Area of crop $c$ produced on land type $g$ \\
\hline$v$ & Livestock & $y_{c g}$ & $\begin{array}{l}\text { Yield function for production of crop } c \\
\text { on land type } g\end{array}$ \\
\hline$L_{v}$ & Stock level of livestock $v$ & $y_{v}$ & $\begin{array}{l}\text { Yield function for livestock } v \text { and } \\
\text { livestock product }\end{array}$ \\
\hline$e_{i}$ & Per unit input cost for input $x_{i}$ & $y_{r}$ & Grass yield of rangeland \\
\hline$j$ & Type of purchased food & $f$ & Purchased food \\
\hline$z_{f}$ & Family labor used on-farm & $Z_{h}$ & Total family labor \\
\hline$Z_{f}$ & Total farm labor input & $w_{k}$ & Wage for hired labor \\
\hline$w_{0}$ & Wage for off-farm labor & $h_{k}$ & Hired labor used on-farm \\
\hline$z_{0}$ & Family labor used off-farm & $\alpha$ & Daily fodder requirement of livestock $\mathrm{v}$ \\
\hline$\gamma$ & $\begin{array}{l}\text { Daily subsistent nutrition } \\
\text { requirement of human }\end{array}$ & $\beta$ & Nutrition content of food \\
\hline$H$ & Human population & $T$ & Supplementary fodder from crop residue \\
\hline$b$ & $\begin{array}{l}\text { Crop or livestock output y used for } \\
\text { self-consumption }\end{array}$ & $S$ & $\begin{array}{l}\text { Crop or livestock output } y \text { used for } \\
\text { self-supply, such as seed, feed, draft animal }\end{array}$ \\
\hline$W_{\text {total }}$ & Total available water resources & $W_{s}$ & Allocated surface water based on quota \\
\hline$W_{g}$ & Available groundwater resources & $\inf$ & Infiltration of mainstream \\
\hline et & Evaporation of runoff & $c f$ & Canal use efficiency coefficient \\
\hline$Q_{c g}$ & Water quota of crop $c$ on land type $g$ & $Q_{v}$ & Water quota of livestock $v$ \\
\hline
\end{tabular}

In the BEM model of the Heihe River Basin, three types of cultivated land are considered: rice field, plain land and hilly land. Twenty kinds of crops are included. The yield of crops depends on land type, the input level of labor, fertilizer (including manure), irrigation, seeds and pesticides. Irrigation water is dealt with as the input of production activities and is very important for determining crop yield in the region. The irrigation water charge per unit hectare is given exogenously. Water input can be derived endogenously according to irrigation water cost and output prices. The shadow price of water resource derived from the BEM model implies the marginal product value of irrigation water under the constraint of the available water resource. Livestock activities include five kinds of animals: sheep, cattle for breeding, cattle for producing beef, pig and poultry. The purpose of crop and livestock products includes sale, self-consumption and self-supply activities. The model also contains the purchase of staple food, 
vegetable and meat for household consumption and seeds, fertilizers, irrigation water and feed for crop and livestock production.

The mathematic forms of the objective function with maximizing net income and constraints are provided below:

$$
\begin{aligned}
& \operatorname{MaxM}=\sum_{c=1}^{C}\left(p_{c}\left(\sum_{g=1}^{G} A_{c g} y_{c g}(x)-b_{c}-S_{c}\right)-\sum_{g=1}^{G} \sum_{i=1}^{n} A_{c g} e_{i c g} x_{i c g}\right)+ \\
& \sum_{v=1}^{V}\left(p_{v}\left(L_{v} y_{v}(x)-b_{v}-S_{v}\right)-\sum_{i=1}^{n} L_{v} e_{i v} x_{i v}\right)-\sum_{j=1}^{J} p_{j} f_{j}+\sum_{o}^{O} w_{o} z_{o}-\sum_{k}^{K} w_{k} h_{k}
\end{aligned}
$$

Subject to:

$$
\begin{aligned}
& A=\sum_{c}^{C} \sum_{g}^{G} A_{c g}+A_{r} \\
& Z_{h}=z_{f}+z_{o} \\
& Z_{f}=z_{f}+\sum_{k}^{K} h_{k} \\
& \sum_{v=1}^{V} 365 \alpha_{v} L_{v} \leq A_{r} y_{r}+T \\
& 365 \gamma H \leq \sum_{c=1}^{C} \beta_{c} b_{c}+\sum_{j=1}^{J} \beta_{j} f_{j} \\
& \sum_{c=1}^{C} \sum_{g=1}^{G} \sum_{i=1}^{n} A_{c g} e_{i c g} x_{i c g}+\sum_{v=1}^{V} \sum_{i=1}^{n} L_{v} e_{i v} x_{i v}+\sum_{j=1}^{J} p_{j} f_{j}+\sum_{k}^{K} w_{k} h_{k} \leq M_{0}+N+D \\
& W_{\text {total }}=\left(W_{s}-i n f-e t\right) \times c f+W_{g} \\
& \sum_{c=1}^{C} \sum_{g=1}^{G} A_{c g} Q_{c g}+\sum_{v=1}^{V} L_{v} Q_{v} \leq W_{\text {total }}
\end{aligned}
$$

The constraints of resource endowment include land area (Equation (2)), family labor (Equations (3) and (4)), livestock feed requirement (Equation (5)), nutritional requirement (Equation (6)), capital (Equation (7)), water resources (Equations (8) and (9)) and crop rotation. Under the capital constraint, the aggregation of cash, loans and subsidies for greenhouse production provides capital for all production activities. Under the constraint of the nutritional requirement, the minimum nutrition needs for a family member should be met by self-sufficient and purchased foods. Under the constraint of irrigation water, surface water and groundwater are allocated between water-intensive crops, such as vegetables, wheat-maize intercropping and water-efficient crops, such as seed corn and cotton.

The BEM model is usually constructed at the household level or village level. This study constructed a GIS-based BEM to illustrate the spatial variations of farmers' response to the water demand control measures and to examine their impacts on farm income and crop production at the irrigation zone level. Of the total of 31 irrigation zones in the Heihe River Basin, 20 irrigation zones are in the middle stream region and 11 irrigation zones in the upstream region (Figure 1). A spot model is built at the irrigation zone level, and each irrigation zone consists of several villages that have a similar cropping system. The model assumes that all famers act rationally in the same manner within an irrigation zone. They will maximize their profits, assuming perfect knowledge and foresight. In the short run, production technologies are assumed to be fixed, and the mix of activities on the farm cannot be changed, so that 
the Leontief production function is adoptable. Resources endowment and production activities vary among different irrigation zones. The 31 spot BEM models were integrated into a distributed BEM model at the river basin level through a GIS platform. A tradeoff of water resource allocation exists across irrigation zones. The GIS-based BEM model simulates farmers' decisions according to the spatial and geographic diversity of the water supply and the crop structure across 31 different irrigation zones.

It should be noted that irrigation water reallocation has taken place only in the middle stream regions, because the upstream regions are independent of the mainstream of the Heihe River.

\subsection{Data Source and Data Description}

In this study, two kinds of parameters are used in the BEM model: resources endowment and input-output coefficients of crops and livestock. The data for the land resource in each irrigation zone are from the statistics data of the research site in 2008, and the data for the water resource and water reallocation plan of the Heihe River Basin are from the Water Resource Official Reports, published every year by the Water Affair Bureau of Zhangye. The dataset for input-output coefficients are obtained by a field survey, which was conducted in August, 2009. It covered 570 households in 45 villages of the five counties in the river basin. The households are chosen by a stratified-random sampling method across 31 irrigation zones. The survey data include crop yield, crop price, fertilizer, pesticide, labor input, subsidies, and so on. Among them, irrigation water input is one of the most important items. Farmers are asked to recount the average length of irrigation time, irrigation times for each crop and the water fee per hectare. Hence, the volume of water applied for each crop can be estimated accurately. The data description of the sampled households is shown in Table 2.

Table 2. Data description of the sampled households.

\begin{tabular}{lcccccc}
\hline & \multicolumn{3}{c}{ Middle Stream Region } & \multicolumn{2}{c}{ Upstream Regions } \\
\cline { 2 - 6 } & Ganzhou & Linze & Gaotai & Minle & Shandan \\
\hline Sampled villages & 14 & 6 & 9 & 10 & 6 \\
Householder & 138 & 108 & 113 & 63 & 90 \\
Population (person) & 581 & 425 & 449 & 265 & 439 \\
Cultivated land (ha) & 79 & 89 & 68 & 73 & 110 \\
\hline Labor (person) & 281 & 208 & 209 & 117 & 201 \\
\hline Proportion of farm labor (\%) & 46 & 54 & 67 & 39 & 35 \\
Proportion of Off-farm labor (\%) & 54 & 46 & 33 & 61 & 65 \\
\hline Income per capita (Yuan/person) & 9913 & 10,867 & 10,917 & 10,799 & 9663 \\
\hline Proportion of agriculture income (\%) & 35 & 50 & 38 & 48 & 35 \\
Proportion of off-farm income (\%) & 65 & 50 & 62 & 52 & 65 \\
\hline Crop structure & \multicolumn{7}{c}{5} & & & \\
\hline Grain crops (\%) & 18 & 11 & 24 & 36 & 37 \\
Cash crop (\%) (including seed corn) & 57 & 75 & 51 & 36 & 41 \\
Other crops (\%) & 25 & 14 & 25 & 29 & 22 \\
\hline
\end{tabular}




\subsection{Model Calibration}

In order to calibrate the BEM model, the "present situation" is set as the baseline to compare with the actual situation in 2008. The simulation results of the calibrated model under "present situation" situation are quite consistent with the actual situation in 2008. The overall bias between the simulation results and actual situation for the sewing area is $17 \%$, and the bias for the crop area in $70 \%$ of the irrigation zones is below 20\%. It is found that the model results are sensitive to the constraints of crop rotation, farm-gate prices, capital input for cattle and subsidies for greenhouse vegetables. The deviation between the simulation results and actual situation may be partially from risk attitude. The model assumed that farmers are economically rational and pursue the maximization of net return. While in the actual world, farmers often avoid risk. For example, our field survey showed that households tend to be reluctant to adopt new agricultural technologies, even when the expected net return is high. Furthermore, households prefer to plant disease-resistant, but low-yielding crops or to plant more drought- and cold-resistant varieties of crops in preparation for an adverse weather event, as they are more sensitive to potential losses than to potential gains.

\section{Results and Discussion}

\subsection{Effects of Changing Runoff on the Shadow Price}

As the present situation (represented by 2008) is a wet year, if runoff changed from the present situation to the annual mean runoff, available water will decline in the middle stream regions. There are three cases for the change of the shadow price of water resources with the reduction of available water (Table 3). Case Q1: In the irrigation zones where available water is able to meet current water requirements, the shadow price of the water resource stays unchanged, even with the reduced available water. Case Q2: In the irrigation zones where the reduction of available water leads to a water shortage, the shadow price of the water resources will rise. Case Q3: In the irrigation zones where available water cannot meet current water requirements under the present situation, there is little change in the shadow price of the water resource with the reduction of available water. As a result, in most irrigation zones where water supply cannot meet water use, the shadow prices of the water resource under the annual mean runoff will be around one Yuan per $\mathrm{m}^{3}$, more than 10-times the current water price (Table 3).

Table 3. The shadow prices of water resources under the present situation and the annual mean runoff in irrigation zones.

\begin{tabular}{|c|c|c|c|c|c|}
\hline \multirow{2}{*}{$\begin{array}{l}\text { Cases of } \\
\text { Irrigation } \\
\text { Zones }\end{array}$} & \multirow[b]{2}{*}{ Regions } & \multirow{2}{*}{$\begin{array}{c}\text { Code for the } \\
\text { Irrigation Zones }\end{array}$} & \multirow[b]{2}{*}{ Description } & \multicolumn{2}{|c|}{$\begin{array}{c}\text { Shadow Price of Water } \\
\text { Resources (Yuan/m³) }\end{array}$} \\
\hline & & & & $\begin{array}{c}\text { Present } \\
\text { Situation }\end{array}$ & $\begin{array}{l}\text { Annual } \\
\text { Mean } \\
\text { Runoff }\end{array}$ \\
\hline Q1 & $\begin{array}{l}\text { Middle } \\
\text { stream } \\
\text { regions }\end{array}$ & $\begin{array}{l}\text { I1-01, I1-03, I1-04, } \\
\text { I3-02,II2-06, II4-06, } \\
\text { II5-06, III4-09, III5-09, } \\
\text { III6-09 }\end{array}$ & $\begin{array}{l}\text { Water surplus irrigation zones } \\
\text { where available water is able to } \\
\text { meet current water requirement } \\
\text { under annual mean runoff }\end{array}$ & 0.082 & 0.083 \\
\hline
\end{tabular}


Table 3. Cont.

\begin{tabular}{|c|c|c|c|c|c|}
\hline \multirow{2}{*}{$\begin{array}{l}\text { Cases of } \\
\text { Irrigation } \\
\text { Zones }\end{array}$} & \multirow[b]{2}{*}{ Regions } & \multirow{2}{*}{$\begin{array}{c}\text { Code for the Irrigation } \\
\text { Zones }\end{array}$} & \multirow[b]{2}{*}{ Description } & \multicolumn{2}{|c|}{$\begin{array}{c}\text { Shadow Price of Water } \\
\text { Resources }\left(\text { Yuan } / \mathbf{m}^{3}\right)\end{array}$} \\
\hline & & & & $\begin{array}{c}\text { Present } \\
\text { Situation }\end{array}$ & $\begin{array}{l}\text { Annual } \\
\text { Mean } \\
\text { Runoff } \\
\end{array}$ \\
\hline Q2 & $\begin{array}{l}\text { Middle } \\
\text { stream } \\
\text { regions }\end{array}$ & $\begin{array}{l}\text { I2-03, II3-07, } \\
\text { II6-07, III1-11 }\end{array}$ & $\begin{array}{l}\text { Irrigation zones where } \\
\text { available water changes } \\
\text { from surplus to shortage } \\
\text { with runoff changes from } \\
\text { present situation to annual } \\
\text { mean runoff }\end{array}$ & 0.082 & 1.133 \\
\hline \multirow[b]{2}{*}{ Q3 } & $\begin{array}{l}\text { Middle } \\
\text { stream } \\
\text { regions }\end{array}$ & $\begin{array}{l}\text { II1-07, III1-09, III2-08, } \\
\text { III2-09, III3-08, III3-10; }\end{array}$ & \multirow{2}{*}{$\begin{array}{l}\text { Water shortage irrigation } \\
\text { zones where available } \\
\text { water cannot meet current } \\
\text { water requirement under } \\
\text { present situation }\end{array}$} & 0.836 & 0.839 \\
\hline & $\begin{array}{l}\text { Upstream } \\
\text { regions }\end{array}$ & $\begin{array}{c}\text { IV1-12, IV1-14, IV2-12, } \\
\text { IV2-14, IV3-13, IV4-14, } \\
\text { V1-12, V1-14, V1-15, } \\
\text { V2-14, I4-05 }\end{array}$ & & 1.553 & 1.550 \\
\hline
\end{tabular}

\subsection{Effects of Raising Water Price}

The simulation results indicate that only when the water price is above the shadow price will water use decrease with the rising water price (Table 4). In Case P1, the irrigation zones have relatively plentiful water resources, and the shadow price (referring to the annual mean, unless otherwise specified) of the water resource (about 0.08-0.09 Yuan per $\mathrm{m}^{3}$ ) is close to the current price of irrigation water. A water price rise leads to a water use decline. These regions have a major contribution to water saving when the water price rises by 10-times. Meanwhile, raising the prices of both surface and groundwater can save much more water than only raising the surface water price. In Case P2 and P3, water resources are scarce and the shadow price of water resources is about 0.91-1.05 Yuan per $\mathrm{m}^{3}$. Farmers will continue to input water for farm production when the opportunity cost of water use is higher than the real cost of water use. Unless the water price was raised more than the shadow price, water use will not decrease with the water price rise. Meanwhile, water use will not decline in the upstream regions, because the shadow price of water resources is high, about 1.40-1.55 Yuan per $\mathrm{m}^{3}$.

The simulation results show that raising the water price has no significant impact on cereal production (Table 4). Farmers strive to be self-sufficient by growing staple crops for their own consumption. 
Table 4. Changes in water requirement and per capita cereal production with water price rise.

\begin{tabular}{|c|c|c|c|c|c|c|c|c|c|c|c|c|c|c|c|}
\hline \multirow{3}{*}{$\begin{array}{c}\text { Case of } \\
\text { Irrigation } \\
\text { Zones }\end{array}$} & \multirow{3}{*}{ Regions } & \multirow{3}{*}{$\begin{array}{c}\text { Code for the } \\
\text { Irrigation Zones }\end{array}$} & \multirow{3}{*}{ Description } & \multicolumn{6}{|c|}{ Change in Water Requirement (million $\mathbf{m}^{3}$ ) } & \multicolumn{6}{|c|}{ Change in per capita cereal production (\%) } \\
\hline & & & & \multicolumn{3}{|c|}{$\begin{array}{c}\text { Effects of Raising Surface and } \\
\text { Ground Water Price }\end{array}$} & \multicolumn{3}{|c|}{$\begin{array}{c}\text { Effects of Raising } \\
\text { Surface Water Price }\end{array}$} & \multicolumn{3}{|c|}{$\begin{array}{c}\text { Effects of Raising Surface and } \\
\text { Ground Water Price }\end{array}$} & \multicolumn{3}{|c|}{$\begin{array}{c}\text { Effects of Raising } \\
\text { Surface Water Price }\end{array}$} \\
\hline & & & & 2 Times & 5 Times & 10 Times & 2 Times & 5 Times & 10 Times & 2 Times & 5 Times & 10 Times & 2 Times & 5 Times & 10 Times \\
\hline P1 & $\begin{array}{l}\text { Middle } \\
\text { stream } \\
\text { regions }\end{array}$ & $\begin{array}{l}\text { I1-01, I1-03, I1-04, } \\
\text { I3-02, II2-06, } \\
\text { II4-06, II5-06, } \\
\text { III4-09, III1-09, } \\
\text { III5-09, III6-09 }\end{array}$ & $\begin{array}{l}\text { Water surplus } \\
\text { irrigation zones under } \\
\text { annual mean runoff }\end{array}$ & -1 & -15 & -78 & -1 & -11 & -71 & -1 & -19 & -16 & 0 & -18 & -19 \\
\hline \multirow[b]{2}{*}{$\mathrm{P} 2$} & $\begin{array}{l}\text { Middle } \\
\text { stream } \\
\text { regions }\end{array}$ & $\begin{array}{l}\text { II1-07, II3-07, } \\
\text { II6-07, III1-11 }\end{array}$ & \multirow{2}{*}{$\begin{array}{l}\text { Water shortage } \\
\text { irrigation zones under } \\
\text { annual runoff and } \\
\text { there is no change of } \\
\text { cropping system with } \\
\text { water price rise }\end{array}$} & 0 & 0 & -31 & 0 & 0 & -20 & 0 & 0 & -15 & 0 & 0 & -8 \\
\hline & $\begin{array}{l}\text { Upstream } \\
\text { regions }\end{array}$ & $\begin{array}{l}\text { V1-14, V1-15, } \\
\text { V2-14, IV1-14, } \\
\text { IV2-14, V3-13, } \\
\text { IV4-14 }\end{array}$ & & 0 & 0 & 0 & 0 & 0 & 0 & 0 & 0 & 0 & 0 & 0 & 0 \\
\hline \multirow{2}{*}{ P3 } & $\begin{array}{l}\text { Middle } \\
\text { stream } \\
\text { regions }\end{array}$ & $\begin{array}{l}\text { I2-03, III2-08, } \\
\text { III2-09, III3-08, } \\
\text { III3-10 } \\
\end{array}$ & \multirow{2}{*}{$\begin{array}{l}\text { Water shortage } \\
\text { irrigation zones under } \\
\text { annual mean runoff } \\
\text { and there are changes } \\
\text { of cropping system } \\
\text { with water price rise }\end{array}$} & 0 & 0 & -49 & 0 & 0 & -46 & -1 & -3 & -7 & 0 & -1 & -3 \\
\hline & $\begin{array}{l}\text { Upstream } \\
\text { regions }\end{array}$ & $\begin{array}{l}\text { I4-05, V1-12, } \\
\text { IV1-12, IV2-12 }\end{array}$ & & 0 & -1 & -18 & 0 & -1 & -18 & -1 & -3 & -7 & -1 & -3 & -5 \\
\hline
\end{tabular}


Table 5. Changes in per capita income with and without compensation.

\begin{tabular}{|c|c|c|c|c|c|c|c|c|}
\hline & \multirow[t]{2}{*}{ Case of Irrigation Zones } & \multirow[t]{2}{*}{ Regions } & \multicolumn{3}{|c|}{$\begin{array}{c}\text { Effects of Raising Surface and } \\
\text { Ground Water Price } \\
\end{array}$} & \multicolumn{3}{|c|}{$\begin{array}{c}\text { Effects of Raising Surface } \\
\text { Water Price }\end{array}$} \\
\hline & & & 2 Times & 5 Times & 10 Times & 2 Times & 5 Times & 10 Times \\
\hline \multirow{5}{*}{$\begin{array}{l}\text { Changes in per capita income } \\
\text { (Yuan/person) }\end{array}$} & P1 & Middle stream regions & -125 & -496 & -1095 & -80 & -317 & -685 \\
\hline & \multirow{2}{*}{ P2 } & Middle stream regions & -145 & -578 & -1309 & -120 & -479 & -1087 \\
\hline & & Upstream regions & -56 & -226 & -513 & -43 & -172 & -390 \\
\hline & \multirow{2}{*}{ P3 } & Middle stream regions & -84 & -336 & -748 & -48 & -192 & -431 \\
\hline & & Upstream regions & -109 & -452 & -1128 & -98 & -406 & -1018 \\
\hline \multirow{5}{*}{$\begin{array}{l}\text { Of which: changes in per capita income } \\
\text { caused by irrigation cost increasing } \\
\text { (Yuan/person) }\end{array}$} & $\mathrm{P} 1$ & Middle stream regions & -49 & -185 & -381 & -31 & -110 & -229 \\
\hline & \multirow{2}{*}{$\mathrm{P} 2$} & Middle stream regions & -51 & -204 & -295 & -42 & -169 & -268 \\
\hline & & Upstream regions & -26 & -103 & -235 & -19 & -77 & -174 \\
\hline & \multirow{2}{*}{ P3 } & Middle stream regions & -43 & -170 & -39 & -24 & -97 & 103 \\
\hline & & Upstream regions & -32 & -138 & -264 & -27 & -110 & -232 \\
\hline \multirow{5}{*}{$\begin{array}{l}\text { Of which: changes in per capita income } \\
\text { caused by production system change } \\
\text { (Yuan/person) }\end{array}$} & P1 & Middle stream regions & -76 & -311 & -714 & -49 & -206 & -456 \\
\hline & \multirow{2}{*}{$\mathrm{P} 2$} & Middle stream regions & -94 & -374 & -1014 & -78 & -310 & -820 \\
\hline & & Upstream regions & -30 & -122 & -278 & -24 & -95 & -216 \\
\hline & \multirow{2}{*}{ P3 } & Middle stream regions & -41 & -166 & -710 & -24 & -95 & -534 \\
\hline & & Upstream regions & -77 & -314 & -865 & -71 & -296 & -785 \\
\hline \multirow{5}{*}{ Compensation (Yuan/person) } & $\mathrm{P} 1$ & Middle stream regions & 100 & 392 & 801 & 64 & 251 & 488 \\
\hline & \multirow{2}{*}{$\mathrm{P} 2$} & Middle stream regions & 121 & 486 & 906 & 101 & 402 & 790 \\
\hline & & Upstream regions & 47 & 188 & 423 & 36 & 145 & 326 \\
\hline & \multirow{2}{*}{ P3 } & Middle stream regions & 64 & 256 & 463 & 37 & 147 & 228 \\
\hline & & Upstream regions & 80 & 317 & 647 & 71 & 280 & 564 \\
\hline
\end{tabular}


Generally speaking, water price rise will lead to a decrease in farm income (Table 5). In addition, raising prices of both surface and groundwater will cause more income loss than only raising the surface water price. However, income losses from a water price rise vary in different irrigation zones. In Case $\mathrm{P} 2$, if the water price is raised less than the shadow price, there is no change in water use and the cropping system. The income loss stems mainly from the increase in irrigation cost. In Case P3, a water price rise may induce changes in the cropping system. Crops with relatively high water consumption tend to decrease, and crops with relatively low water consumption increase, because the water price rise resulted in a higher input cost for the high water consuming crops. This may narrow the profit gap between the crops with high or low profits per unit of water use, leading to a profit decrease for the crop production. In addition, when the water price increased so much that the cost exceeded the benefit of crop production, farmers were likely to abandon partially their farmland. In Case P1, a water price rise may lead to a decrease in water use and a change in the cropping system. In this case, the income loss stems from increased irrigation cost and the opportunity cost of the decrease in water use, as well as a change in the cropping system. Significant income losses occur in Linze County and the Gaotai hilly regions, because their current water price is close to the shadow price of water resources. A water price rise may lead to a decrease in water use and a change in the cropping system.

In order to offset income losses caused by the water price rise, a compensation mechanism is taken into consideration. Assuming that the increased water charge can be fully returned to farmers by the water management agency, the amount of compensation is equal to increased water charges of two-times, five-times and ten-times, respectively. For the price control, income changes with compensation vary across different irrigation zones (Table 5). In the irrigation zones with a high shadow price for water resources (Case P2), the income loss stemming from an increase in irrigation cost can be offset mostly by compensation. In the irrigation zones where the shadow price of water resources is close to the current water price and a water price rise may induce a change in the cropping system (Case P3), the increased irrigation cost can be offset by compensation, but income loss due to cropping system change will remain. In the irrigation zones where the current water price is close to the shadow price of water resources and a water price rise may lead to a decrease in water use and a change in the cropping system (Case P1), the increased irrigation cost can be offset by compensation, but the profit decrease due to water use reduction and the change in the cropping system might cause a significant income loss.

It should be emphasized that the amount of compensation to the water price increase is generally smaller than the amount of the total income losses for almost all of the regions of different types of irrigation zones (Table 5). This is because, when the irrigation water price increases, farmers' income will be lowered by both the higher irrigation cost and the changes in the production system, which is characterized by the decrease in cultivated area and replacing high water consuming crops with low water consuming crops.

\subsection{Effects of Reducing Water Allocation Quota Control}

The analysis of the effects of reducing water allocation is based on the three cases shown in Table 3. Under Case Q1, when the water allocation was reduced, the available water cannot meet the water requirement (Table 6). The shadow price of water resources will rise to around 0.948 Yuan per $\mathrm{m}^{3}$. Under Cases Q2 and Q3, water scarcity will be intensified with the reduction of water allocation, and 
the shadow price of the water resource will rise slightly, but basically maintain at a level of around one Yuan per $\mathrm{m}^{3}$.

Table 6. Changes of the shadow price of water resources, water use, farm income and cereal production with reduced water allocation.

\begin{tabular}{|c|c|c|c|c|c|c|c|}
\hline $\begin{array}{c}\text { Case of } \\
\text { Irrigation } \\
\text { Zones }\end{array}$ & Regions & $\begin{array}{c}\text { Shadow Price } \\
\text { of Annual } \\
\text { Mean Runoff }\end{array}$ & $\begin{array}{c}\text { Shadow Price } \\
\text { of Reducing } \\
\text { Water } \\
\text { Allocation }\end{array}$ & $\begin{array}{c}\text { Change in } \\
\text { Water } \\
\text { Requirement }\end{array}$ & $\begin{array}{c}\text { Change in Per } \\
\text { Capita } \\
\text { Income }\end{array}$ & $\begin{array}{c}\text { Change in } \\
\text { Per Capita } \\
\text { Cereal } \\
\text { Production }\end{array}$ & Compensation \\
\hline & & $\left(\right.$ Yuan/m $\left.\mathbf{m}^{3}\right)$ & $\left(\right.$ Yuan/m $\left.\mathbf{m}^{3}\right)$ & (Million $\mathbf{m}^{\mathbf{3}}$ ) & (Yuan/Person) & $(\%)$ & (Yuan/Person) \\
\hline Q1 & $\begin{array}{l}\text { Middle stream } \\
\text { regions }\end{array}$ & 0.083 & 0.948 & -232 & -98 & 0 & 879 \\
\hline Q2 & $\begin{array}{l}\text { Middle stream } \\
\text { regions }\end{array}$ & 1.133 & 1.280 & -16 & -97 & -20 & 174 \\
\hline Q3 & $\begin{array}{l}\text { Middle stream } \\
\text { regions }\end{array}$ & 0.839 & 0.963 & -15 & -50 & 0 & 84 \\
\hline
\end{tabular}

The effect of the reduction in water allocation on farmer income varies across cases (Table 6). Under Case Q1, the reduction of excessive water use does not necessarily lead to a decrease in farm income. However, when the water further reduces to fail to meet the water requirements, farm income begins to decrease. Under Cases Q2 and Q3, any amount of reduction in water use will cause income losses for farmers. In most of the irrigation zones in the middle stream and upstream regions, available water cannot meet current water requirements when irrigation water allocation is reduced, and farmers will suffer various degrees of income loss.

The decrease in the total crop sown areas may lead to a slight decrease of per capita cereal production. Generally speaking, reducing water allocation has no significant impact on food security, as long as long as total income increases.

\subsection{Comparison of Income Losses of Water Saving under the Quantitative Control and Price Control}

As shown in Figure 3, raising water price by 10-times and reducing water allocation can achieve similar water saving effects, but income losses are different. Raising water price by 10-times will cost much more than reducing water allocation in order to save the same volume of irrigation water. However, in few water-rich irrigation zones, raising water price by 10-times may save more water than the quantitative control.

Despite the different compensation levels for the price control and quantitative control, the income loss from the price control will be overall higher than that from the quantitative control.

For the quantitative control, as a reduction of water allocation means profit loss from water use for farmers, the compensation for income loss can refer to the shadow price of water resources. Given the average net profit of per unit irrigation water use of about 1.5 Yuan per $\mathrm{m}^{3}$, the compensation under quantitative control is set at 1.5 Yuan per $\mathrm{m}^{3}$. When the income loss of farmers is compensated for by the industrial sector, compensation for income loss is similar to water trading between agriculture and industrial water use. The current price of industrial water use in Zhangye city is four Yuan per $\mathrm{m}^{3}$, so a compensation of 1.5 Yuan per $\mathrm{m}^{3}$ for income loss should be acceptable by the industrial sector. 
Figure 3. Comparison of the impacts of quantitative control and price control on farm income.

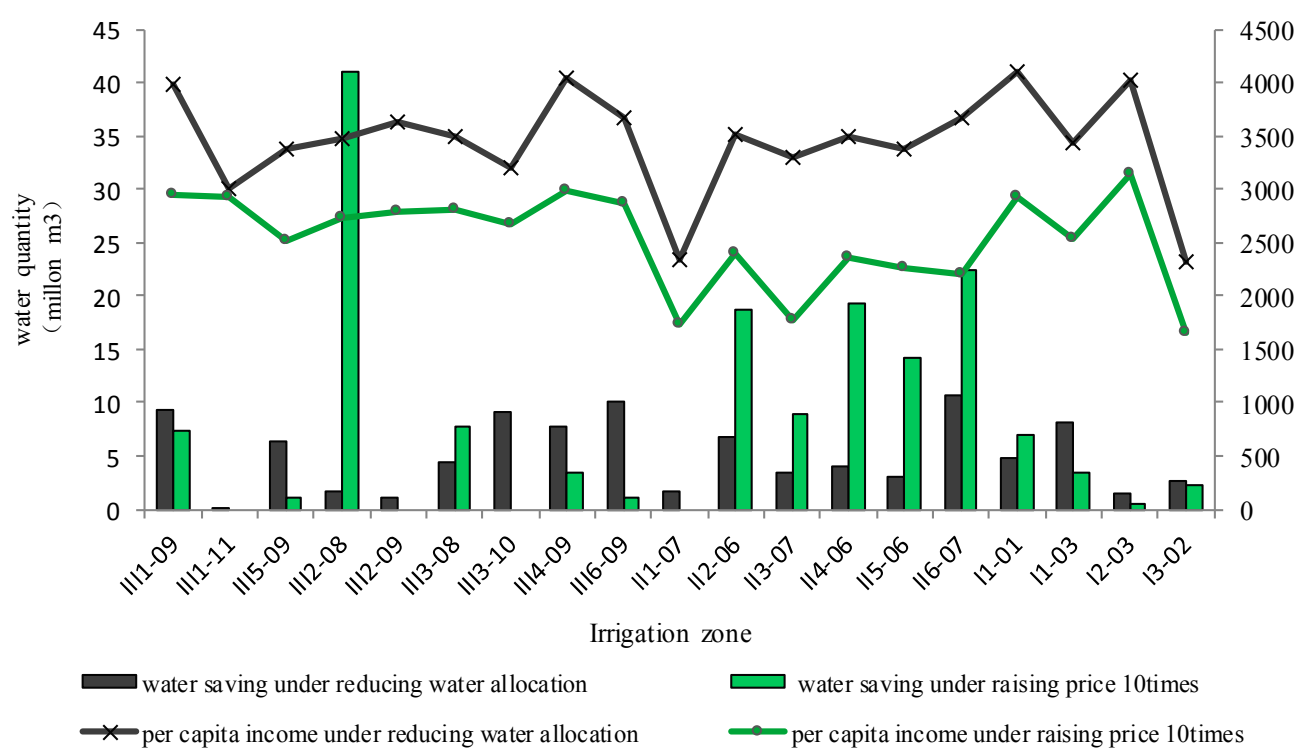

\section{Main Findings and Conclusions}

This study examined farmers' response to policy instruments for water demand management and compared the effects of quantitative control and price control on farm income and crop production in the Heihe River Basin. The main findings are summarized below:

Firstly, in water scarce regions, where the current price of irrigation water is far below the shadow price of water resources, farmers are generally not responsive to a relatively small water price increase. Reducing water demand requires a large price rise for irrigation water, which will lead to a big loss of farm income and high negative impacts on crop production. As the total income loss due to the increasing water charge cannot be compensated fully by only returning the additional water charge to the farmers (Table 5), the government would have to bear with the difference, which can be a significant fiscal burden to the local government.

Secondly, compared with price control, the quantitative control measure can save an equal volume of water with a lower cost. This indicates that quantitative control is more cost-effective for the purpose of reducing water use in agriculture. The amount of compensation to cover the total income loss is lower for the quantitative control than for price control measure. As the transferred water volume is known under the quantitative control measure, the farmers' income losses (including opportunity cost) can be compensated for by the industries that receive the transferred water. The local government needs just to recover the losses from irrigation water fee for the water supply bureaus. Under the price control measure, the reduction of irrigation water use is unknown in advance. The local government needs to pay income compensation to farmers in advance and then impose a water fee on the industries that use the transferred water. The transaction cost could be high.

Thirdly, in relatively water-rich regions, where the current price of irrigation water is close to the shadow price of water resources, farmers will be responsive to a price change when the water price is raised to the level of the shadow price. In this case, the price control measure may be a realistic choice 
to induce water saving. The price increase of irrigation water will cause a relatively small negative impact on farm income and crop production.

Finally, although the simulation results support the quantitative control measure, decision makers need to examine the tradeoffs by taking into account feedback from stakeholders, including farmers, agricultural technicians and local governmental officials.

\section{Acknowledgments}

The authors thank the major research plan of the National Natural Science Foundation of China (Grant No. 91325302) and the China National Key project from the Ministry of Science and Technology (No. 2009CB421308)

\section{Author Contributions}

Minjun Shi conceived of the research and wrote the paper. Xiaojun Wang performed the survey and analyzed the data. Hong Yang provided academic advice throughout the process and helped to revise the manuscript. Tao Wang provided academic advice throughout the process. All authors approved the final manuscript.

\section{Conflicts of Interest}

The authors declare no conflict of interest.

\section{References}

1. Chen, Y.; Zhang, D.Q.; Sun, Y.B.; Liu, X.N.; Wang, N.Z.; Savenije, H.H.G. Water demand management: A case study of the heihe river basin in china. Phys. Chem. Earth 2005, 30, 408-419.

2. Qu, F.; Kuyvenhoven, A.; Shi, X.; Heerink, N. Sustainable natural resource use in rural China: Recent trends and policies. China Econ. Rev. 2011, 22, 444-460.

3. Ward, F.A.; Pulido-Velazquez, M. Water conservation in irrigation can increase water use. Proc. Natl. Acad. Sci. USA 2008, 105, 18215-18220.

4. Wietzman, M. Prices vs. quantities. Rev. Econ. Stud. 1974, 41, 477-491.

5. Cosgrove, W.J.; Rijsberman, F.R. World Water Vision: Making Water Everybody's Business; Earthscan: London, UK, 2000.

6. Tsur, Y.; Dinar, A. The relative efficiency and implementation costs of alternative methods for pricing irrigation water. World Bank Econ. Rev. 1997, 11, 243-262.

7. European Union (EU). Establishing a framework for community action in the field of water policy (2000/60/EC). Off. J. Eur. Commun. 2000, 327, 1-72.

8. Kampas, A.; Petsakos, A.; Rozakis, S. Price induced irrigation water saving: Unraveling conflicts and synergies between European agricultural and water policies for a Greek Water District. Agric. Syst. 2012, 113, 28-38.

9. Varela-Ortega, C.; Sumpsi, J.M.; Garrido, A.; Blanco, M.; Iglesias, E. Water pricing policies, public decision making and farmers' response: Implications for water policy. Agric. Econ. 1998, 19, 193-202. 
10. Yang, H.; Zhang, X.H.; Zehnder, A.J.B. Water scarcity, pricing mechanism and institutional reform in northern China irrigated agriculture. Agric. Water Manag. 2003, 61, 143-161.

11. Abu-Madi, M.O. Farm-level perspectives regarding irrigation water prices in the Tulkarm district, Palestine. Agric. Water Manag. 2009, 96, 1344-1350.

12. Molle, F. Water scarcity, prices and quotas: A review of evidence on irrigation volumetric pricing. Irrig. Drain. Syst. 2009, 23, 43-58.

13. Gallego-Ayala, J.; Gomez-Limon, J.A.; Arriaza, M. Irrigation water pricing instruments: A sustainability assessment. Spanish J. Agric. Res. 2011, 9, 981-999.

14. Wei, Y.P.; Chen, D.L.; Hu, K.L.; Willett, I.R.; Langford, J. Policy incentives for reducing nitrate leaching from intensive agriculture in desert oases of Alxa, Inner Mongolia, China. Agric. Water Manag. 2009, 96, 1114-1119.

15. Wei, Y.P.; Davidson, B.; Chen, D.L.; White, R. Balancing the economic, social and environmental dimensions of agro-ecosystems: An integrated modeling approach. Agric. Ecosyst. Environ. 2009, $131,263-273$.

16. Huang, Q.Q.; Rozelle, S.; Howitt, R.; Wang, J.X.; Huang, J.K. Irrigation water demand and implications for water pricing policy in rural China. Environ. Dev. Econ. 2010, 15, 293-319.

17. Appels, D.; Douglas, R.; Dwyer, G. Responsiveness of Demand for Irrigation Water: A Focus on the Southern Murray-Darling Basin; Productivity Commission: Melbourne, Australia, 2004.

18. Scheierling, S.M.; Loomis, J.B.; Young, R.A. Irrigation water demand: A meta-analysis of price elasticities. Water Resour. Res. 2006, doi:10.1029/2005WR004009.

19. Olmstead, S.M.; Michael Hanemann, W.; Stavins, R.N. Water demand under alternative price structures. J. Environ. Econ. Manag. 2007, 54, 181-198.

20. Davidson, B.; Hellegers, P. Estimating the own-price elasticity of demand for irrigation water in the Musi catchment of India. J. Hydrol. 2011, 408, 226-234.

21. Bate, R. Water- can property rights and markets replace conflict? In Sustainable Development: Promoting Progress or Perpetuating Poverty? Morris, J., Ed.; Profile Books: London, UK, 2002.

22. Tsur, Y.; Dinar, A. Efficiency and Equity Considerations in Pricing and Allocating Irrigation Water; World Bank Publications: Washington, DC, USA, 1995; Volume 1460.

23. Mohamed, A.S.; Savenije, H.H.G. Water demand management: Positive incentives, negative incentives or quota regulation? Phys. Chem. Earth Part B Hydrol. Oceans Atmos. 2000, 25, 251-258.

24. Wichelns, D. Economic analysis of water allocation policies regarding nile river water in Egypt. Agric. Water Manag. 2002, 52, 155-175.

25. Mul, M.L.; Kemerink, J.S.; Vyagusa, N.F.; Mshana, M.G.; van der Zaag, P.; Makurira, H. Water allocation practices among smallholder farmers in the South Pare Mountains, Tanzania: The issue of scale. Agric. Water Manag. 2011, 98, 1752-1760.

26. Vos, J.; Vincent, L. Volumetric water control in a large-scale open canal irrigation system with many smallholders: The case of Chancay-Lambayeque in Peru. Agric. Water Manag. 2011, 98, 705-714.

27. Liao, Y.S.; Gao, Z.Y.; Bao, Z.Y.; Huang, Q.W.; Feng, G.Z.; Xu, D.; Cai, J.B.; Han, H.J.; Wu, W.F. China's Water Pricing Reforms for Irrigation: Effectiveness and Impact; International Water Management Institute: Sri Lanka, Colombo, 2008. 
28. Wang, J.X.; Huang, J.K.; Xu, Z.G.; Rozell, S.; Hussain, I.; Biltonen, E.; Huang, Q.Q.; Msangi, S. Pro-poor intervention strategies in irrigated agriculture in Asia: Poverty in irrigated agriculture: Issues and options: China. Irrig. Drain 2007, 56, 119-126.

29. Webber, M.; Barnett, J.; Finlayson, B.; Wang, M. Pricing China's irrigation water. Glob. Environ. Change-Hum. Policy Dimens. 2008, 18, 617-625.

30. Shen, Y.; Lein, H. Treating water as an economic good: Policies and practices in irrigation agriculture in Xinjiang, China. Geogr. J. 2010, 176, 124-137.

31. Fragoso, R.; Marques, C. The Economic Impact of Alternative Water Pricing Policies in Alentejo Region; University of Evora: Evora, Portugal, 2013.

32. Li, X.; Tian, Z. Practices and Reflections on Establishing a Water-Saving Society; China Water Press: Beijing, China, 2003. (In Chinese)

33. Berbel, J.; Mateos, L. Does investment in irrigation technology necessarily generate rebound effects? A simulation analysis based on an agro-economic model. Agric. Syst. 2014, 128, 25-34.

34. Aucamp, D.C.; Steinberg, D.I. The computation of shadow prices in linear programming. J. Oper. Res. Soc. 1982, 33, 557-565.

35. Shi, M.J.; Zhang, Q.Y.; Wang, T. Better access to new technologies and credit service, farmers' land use decision, and policy for poverty alleviation and rangeland conservation. Jarq-Jpn. Agric. Res. Q. 2005, 39, 181-190.

36. Janssen, S.; van Ittersum, M.K. Assessing farm innovations and responses to policies: A review of bio-economic farm models. Agric. Syst. 2007, 94, 622-636.

(C) 2014 by the authors; licensee MDPI, Basel, Switzerland. This article is an open access article distributed under the terms and conditions of the Creative Commons Attribution license (http://creativecommons.org/licenses/by/4.0/). 